\title{
doispontos:
}

\section{Judicialização da Política, Auto-restrição judicial e a Defesa da Constituição: algumas lições de Carl Schmitt em Der Hüter der Verfassung. ${ }^{1}$}

\author{
"O clamor por um guardião e defensor da Constituição é, na maioria das \\ vezes, um sinal de delicadas condições constitucionais." \\ Carl Schmitt. Der Hüter der Verfassung, 1931.
}

\author{
Cláudio Ladeira de Oliveira²
}

Resumo: Neste artigo apresento uma interpretação das teses de Carl Schmitt apresentadas em sua obra Der Hüter der Verfassung, O Guardião da Constituição. Inicialmente, (2) apresento a definição schmittiana de "guardião da Constituição", por oposição a um "senhor e soberano da Constituição", comparando-a com abordagens contemporâneas da teoria constitucional. Em seguida utilizo esses conceitos para discutir as teses de Schmitt sobre (3) a função do presidente do Reich como guardião da Constituição; (4) a defesa de uma postura de auto-restrição no exame judicial de constitucionalidade das leis; e (5) sua crítica à "judicialização da política". Por fim, (6) utilizo essas teses para discutir a função do Supremo Tribunal Federal brasileiro e questionar seu status de "guardião da Constituição". Palavras-chave: guardião da constituição; Carl Schmitt; Judicialização da política; auto-restrição judicial.

\begin{abstract}
In this article I present an interpretation of Carl Schmitt's theses presented in his work Der Hüter der Verfassung, The Guardian of the Constitution. Initially, (2) I present the Schmittian definition of "guardian of the Constitution", as opposed to a "lord and sovereign of the Constitution", comparing it with contemporary approaches to constitutional theory. I then use these concepts to discuss Schmitt's theses on (3) the role of the Reich president as guardian of the Constitution; (4) the defense of a self-restrained stance in the judicial review of the constitutionality of laws; and (5) his criticism of the "judicialization of politics". Finally, (6) I use these theses to discuss the role of the Brazilian Supreme Court and question its status as "guardian of the Constitution".
\end{abstract}

Keywords: guardian of the constitution; Carl Schmitt; Judicialization of politics; judicial self-restrain. 


\section{Introdução.}

Neste artigo pretendo extrair algumas lições da obra Der Hüter der Verfassung ("O Guardião da Constituição"), de Carl Schmitt (2016), publicada originalmente em 1931 a partir do desenvolvimento de alguns artigos escritos e publicados nos dois anos anteriores. Escrevendo nos caóticos anos finais da República de Weimar, Carl Schmitt defendeu a tese de que a Constituição alemã então em vigor atribuía ao presidente da República (do Reich) as competências institucionais para atuar como "o guardião da Constituição". Jurista católico e conservador, alinhado aos governos de direita que até 1933 buscaram sem sucesso - formar um governo estável sem a participação do emergente partido Nazista, no contexto de uma república parlamentarista altamente fragmentada partidariamente, em meio a uma brutal crise política e econômica, as teses de Schmitt desde então suscitaram intermináveis polêmicas.

Acredito que Der Hüter der Verfassung contém lições que ultrapassam o contexto particular no qual a obra foi redigida, úteis à defesa de uma constituição democrática, sobretudo em época de crise institucional. A partir de uma interpretação da Constituição de Weimar, Schmitt desenvolve uma crítica à capacidade de tribunais para efetivamente atuarem como "guardiões" da Constituição e identifica riscos de potenciais ofensas à Constituição no exercício da jurisdição. E suas teses exemplificam um modelo teórico que Adrian Vermeule (2014) denomina "constitucionalismo de otimização", uma abordagem da função que Constituições devem desempenhar face aos riscos de arbitrariedade política oriundos do sistema político.

No item (2), discuto a definição schmittiana de "guardião da constituição", apresentando-a como um arranjo institucional ao qual ele opõe um "senhor e guardião da Constituição". Nos itens seguintes, utilizo essas definições para (3) interpretar as teses de Schmitt sobre a função do presidente do Reich no regime de Weimar, (4) a necessidade de autocontenção judicial no exercício da jurisdição constitucional e (5) a crítica à judicialização da política. Mais do que uma interpretação plausível daquele contexto políticoinstitucional, Schmitt apresenta teses uteis ao debate contemporâneo, por exemplo sobre o status do STF brasileiro como "guardião" da Constituição de 1988, que é discutido no item (6).

\section{2. "Guardião da constituição", "senhor soberano da constituição" e o constitucionalismo de otimização.}

Inicialmente é preciso compreender qual é o significado que Schmitt atribui à expressão "guardião da Constituição". No início da terceira parte de Der Hüter der Verfassung, Schmitt opõe duas formas institucionais distintas, ambas capazes de enfrentar conflitos decorrentes das "divergências de opinião e diferenças entre os titulares de direitos de decisão política e de influência política" (2016, p. 132): (i) um "senhor e soberano do Estado", "um poder político mais forte situado acima das opiniões divergentes", isto é, "um terceiro superior" que não seria o guardião da constituição, mas sim "o senhor soberano do Estado" (p. 132); e (ii) um "Guardião da Constituição", uma instituição graças à qual as divergências são conciliadas por meio de um órgão ao qual os demais poderes se encontram "não em uma relação de subordinação, mas de coordenação"; um "terceiro neutro" que está situado "não acima, mas ao lado de outros poderes constitucionais, mas com poderes e possibilidades peculiares de intervenção" (p. 132).

Essas definições necessariamente excluem a possibilidade de que um governante autoritário, imune a quaisquer limitações constitucionais, como um presidente da República ditatorial por exemplo, possa ser considerado um "guardião" da Constituição. Ao contrário, um tal agente seria um "senhor e soberano do Estado", posto que superior aos demais poderes de Estado, aos quais os demais estariam subordinados. O guardião encontra-se em relação de "coordenação", não "subordinação", com os demais poderes, cujas divergências de opinião deve arbitrar. Em toda a obra, a hipótese do "senhor e soberano" não surge como uma alternativa institucional a ser considerada realmente como opção. Ela é utilizada apenas heuristicamente, 
para identificar o arranjo institucional que, em respeito à separação de poderes, precisa ser evitado. A defesa da Constituição exige um "guardião", não um "senhor e soberano".

E qual instituição deve desempenhar a função de guarda da constituição? Schmitt sugere que "devam ser organizadas uma instituição e uma instancia especiais", insistindo que é importante "não confiar [essa competência] a nenhum dos poderes existentes, pois senão obteria apenas um sobrepeso perante os demais e poderia ele próprio se esquivar do controle. Isso o tornaria então o senhor da Constituição" (2016, p. 132). Em 1914, quinze anos antes dedicar-se de forma mais sistemática ao problema do "guardião da constituição", mencionando de passagem o problema da imposição das leis em geral, Schmitt afirma que "nenhuma lei pode se auto-impor, são sempre apenas pessoas que podem ser incumbidas de manter a lei, e se você não confia nos guardiões, isso não ajuda em dar-lhes novos guardiões" (SCHMITT, 1914, p. 83). Agora é possível afirmar que ele enfrenta o problema mais específico da garantia da efetividade da Constituição, mas a partir do mesmo pressuposto: nenhuma Constituição pode se "auto-impor", "são sempre apenas pessoas", seres humanos reais, que podem desempenhar a função de defesa da Constituição. E as alternativas são basicamente duas: um arranjo equilibrado entre os poderes existentes ou, o que a rigor deixa de ser um guardião e torna-se um "senhor soberano", a concentração dos poderes numa única autoridade, um "um terceiro superior" acima dos demais poderes. Para usar expressões contemporâneas, Schmitt enfrenta do problema partindo do pressuposto de que "não há nada externo à sociedade" (ELSTER, 2000, p. 127). ${ }^{3}$ Por isso tem razão Andreas Kalyvas (2008), quando afirma que o objetivo da teoria constitucional de Carl Schmitt é enfrentar "um dos mais incômodos problemas da teoria democrática moderna - nomeadamente, o problema da auto-imposição e auto-limitação de uma ordem democrática” (KALYVAS, 2008, p. 129).

Afinal, se a Constituição não possui uma força "intrínseca" que a torne "auto-impositiva" e se não existe algum agente e/ou instituição "externo à sociedade" apto a desempenhar a tarefa, as alternativas são essencialmente as duas indicadas por Schmitt: ou um agente hierarquicamente superior aos demais poderes de Estado, um soberano; ou um agente que se encontra "ao lado", em condições de coordenação com os demais poderes. Mais uma vez, tem razão Kalyvas: "embora seja verdade que ele [Schmitt] não era bem disposto em relação a procedimentalismos e formalismo jurídico, é inexato pensar que ele os rejeitava" (KALYVAS, 2008, p. 137). Afinal, de que outro modo seria possível definir uma relação de coordenação entre poderes e instituições do Estado sem algum procedimento e formalismo jurídico ${ }^{4}$

Essas definições conferem plausibilidade à tese de Adrian Vermeule e Eric Posner (2016), que pretendem reconstruir as teses de Schmitt considerando-as formulações intuitivas e embrionárias das abordagens contemporâneas na ciência política e a teoria constitucional:

[...] nós interpretamos suas idéias nos termos dos trabalhos recentes sobre os fundamentos políticos do constitucionalismo. A distinção de Schmitt entre Legalidade e Legitimidade, nós sugerimos, se apoia no insight impecável de que as normas constitucionais valem tanto quanto barreiras de pergaminho, a menos que estejam suportadas pelas estratégias políticas de equilíbrio dos agentes de Estado, cidadãos, partidos políticos e outros atores. (VERMEULE, POSNER, 2016, p. 613). ${ }^{5}$

\footnotetext{
3"Schmitt pode ser lido como antecipando as idéias de Elster e Holmes sobre o constitucionalismo como pré-compromisso" (KALYVAS, 2008, p. 134, nota 24)

${ }^{4} \mathrm{E}$ ainda: "Schmitt não descartou completamente os procedimentos. Ele simplesmente rejeitou sua apropriação por discursos liberais que pretendem ou desprezar o momento substantivo da legitimidade democrática ou ocultar os objetivos e interesses parciais dos grupos sociais sob um véu de neutralidade, imparcialidade e legalidade." (KALYVAS, 2008, p. 137)

${ }^{5}$ É possível comparar com Adam Przeworski (1994): "Uma democracia está consolidada quando, dentro e determinadas condições econômicas e políticas, um sistema específico de instituições torna-se regra geral, quando ninguém consegue imaginar-se agindo fora das instituições democráticas e quando tudo o que os perdedores desejam é tentar outra vez, no quadro das mesmas instituições sob as quais acabam de ser derrotados. Uma democracia está consolidada quando se faz respeitar espontaneamente, isto é, quando todas as forças políticas relevantes acreditam que é melhor para elas continuar subordinando seus interesses e valores à interação incerta das instituições." (PRZEWORSKI, 1994, p. 46)
} 
Acredito que a reconstrução que Vermeule Posner empreendem de Schmitt é correta, mas meu objetivo neste artigo é discutir algo mais pontual e que não é tratado por eles ${ }^{6}$. As teses de Schmitt em Der Hüter der Verfassung podem ser compreendidas como um exemplo de uma perspectiva teórica o próprio Vermeule (2014) denomina "constitucionalismo de otimização". A ele Vermeule opõe o "constitucionalismo de precaução", um modelo teórico que também é útil por sintetizar postulados contra os quais Schmitt se dirigia. Essas expressões, constitucionalismo de precaução e constitucionalismo de otimização, são duas construções conceituais artificiais que Vermeule utiliza para sistematizar abordagens teóricas sobre a função que Constituições devem desempenhar, abordagens essas que no essencial estão implícitas ou articuladas intuitivamente na teoria constitucional moderna. Essas expressões não identificam "escolas doutrinárias realmente existentes”, mas sim dois tipos extremos e antagônicos de respostas ao problema do risco de arbitrariedade política.

O chamado "Constitucionalismo da precaução" objetiva "minimizar" o risco político, reduzindo-o ao máximo. Ele recomenda que as constituições sejam redigidas e interpretadas com o objetivo de criar ao máximo precauções contra o risco de arbitrariedades das instituições políticas. Expressa uma postura generalizada de desconfiança - quando não rejeição - à política que é frequente na doutrina constitucional contemporânea. $\mathrm{O}$ "ônus da prova" argumentativa recai sobre os agentes políticos, que devem demonstrar que a linha de ação adotada no enfrentamento de algum problema específico não oferece riscos de arbitrariedade, corrupção, tirania etc. E em caso de dúvida, "por precaução", deve-se rejeitar tais atos como inválidos (VERMEULE, 2014, p. 10 e ss).?

O "constitucionalismo de otimização", pelo contrário, não objetiva minimizar o risco político, mas "otimizá-lo". Algum risco político sempre será inevitável, resultando tanto da ação quanto da inação: todos os riscos políticos contam! Não apenas é impossível alcançar uma situação de risco político "zero", mas ainda mais grave: as medidas de enfrentamento do risco político podem ser, elas próprias, fonte de risco político. Assim, a fixação exagerada no enfrentamento e algum risco político específico pode agravar o risco político "agregado". As consequências práticas do modelo de "otimização do risco político" é melhor compreendida mediante os argumentos que são apresentados contra as medidas "precaucionarias". As precauções devem ser rejeitadas por (VERMEULE, 2014, pp. 54 e ss).

A crítica "otimizante" é útil, em primeiro lugar, para destacar a possível "futilidade" das medidas precaucionarias. Para que funcionem, os remédios institucionais contra a arbitrariedade política devem fornecer incentivos capazes de estimular os agentes políticos (responsáveis por efetivar as precauções) a agirem quando isso se faz necessário. No entanto, é um erro comum ignorar que as mesmas condições objetivas que tornam a precaução necessária, faz também com que os agentes contra os quais as precauções são estabelecidas tenham incentivos para ignorá-las. Ao mesmo tempo, e pelas mesmas razões, nenhum outro agente terá incentivos para agir e enfrentar os custos de implementação das medidas. Em segundo lugar, a crítica otimizante identifica a "ameaça" produzida pelas medidas precaucionarias. Mesmo quando eficazes, produzem custos que dificultam a realização de outros objetivos constitucionalmente legítimos ou que impedem o enfrentamento de outros riscos políticos, tão ou mais perniciosos. Em terceiro lugar,

\footnotetext{
${ }^{6}$ Para uma aplicação das teses de Schmitt à análise do poder executivo nas democracias contemporâneas, cf. Eric Posner e Adrian Vermeule (2010)

${ }^{7}$ Um tema essencial ao constitucionalismo precaucionário é a desconfiança quanto às motivações dos indivíduos que integram maiorias legislativas e o poder executivo de um modo geral. Considera-se que tais agentes buscam sempre maximizar seu poder e promover os interesses de grupos de pressão poderosos em detrimento do conjunto de cidadãos: "se é possível que ocorra abuso de poder, isso ocorrerá" (VERMEULE, 2014, p. 48). Daí a precaução generalizada contra o exercício do poder administrativo discricionário e as interpretações legislativas de princípios constitucionais abstratos. O mesmo raciocínio válido para o nível individual, aplica-se também ao nível institucional: "se as instituições podem expandir seu poder, elas expandirão" (VERMEULE, 2014, p. 48).
} 
a crítica otimizante identifica a "perversidade" que resulta das medidas precaucionárias. Esse argumento destaca a possibilidade de que a medida precaucionaria adotada para reduzir ao máximo certo o risco de arbitrariedade política pode agravar o problema que deveria combater.

As críticas de Schmitt à possibilidade de que os tribunais atuem como "guardiães da Constituição" exemplificam argumentos de "futilidade". Em sua análise do exame judicial material de constitucionalidade, Schmitt não critica diretamente os tribunais alemães por se autoproclamarem titulares dessa competência enquanto tal. O que ele rejeita não é a existência pura e simples de competências para a declaração judicial de inconstitucionalidade das leis, mas a idéia de que, em virtude do exercício do controle difuso de constitucionalidade, os tribunais possam ser considerados "guardiões da constituição":

O guardião da constituição não é, portanto, um dos muitos órgãos e pessoas que, ao não aplicarem ocasionalmente leis inconstitucionais ou ao não cumprirem ordens inconstitucionais, podem ajudar a garantir que a constituição seja respeitada e que um interesse constitucionalmente protegido não seja violado. Essa é a consideração sistemática que justifica não considerar o tribunal como guardião da constituição, mesmo que eles exerçam o direito judicial acessório e difuso de exame. (SCHMITT, 2016, p. 20).

Ele expressamente admite que uma tal competência para negar aplicação a leis que contradigam a constituição pode desempenhar um papel positivo, promovendo o "respeito à constituição" e os interesses por ela protegidos. E além disso, defende a aprovação de um "direito de exame judicial defensivo" capaz de "salvaguardar o status constitucional do judiciário", uma espécie de "autoproteção do tribunal" contra interferências indevidas dos outros poderes (2016, p. 16). E reconhece que quanto a isso "os tribunais podem fazer a guarda de parte da constituição, a saber, a que diz respeito à sua própria base e posição, as disposições sobre a independência do judiciário." (2016, p. 16). Mas contra a expectativa de que o controle judicial possa funcionar efetivamente como "precaução" contra governos arbitrários, "ditaduras das maiorias" ou golpes de estado, é necessário observar que os mesmos fatores que explicam a opção dos agentes políticos pela ruptura institucional, servem também para explicar a falta de disposição e/ou capacidade dos órgãos de controle para agirem como "guardiões" da Constituição. Por exemplo, tribunais constitucionais podem aderir voluntariamente ao novo regime, uma vez que seus membros não estão apartados do contexto social no qual o conflito institucional ocorre. Ou podem ser simplesmente incapazes de impedir a ação de forças armadas ou maiorias políticas mobilizadas. $\mathrm{Ou}$, ainda, se os membros do tribunal são escolhidos pelos demais poderes, é possível que com o tempo a corte simplesmente passe a integrar a coalização de forças dominante ${ }^{8}$. Afinal, tribunais não tem força para adotar as medidas políticas efetivamente necessárias para defender a constituição no momento em que a existência da Constituição encontra-se realmente ameaçada: "Tanto o judiciário quanto os funcionários públicos serão sobrecarregados de maneira insuportável se todos estiverem amontoados com as tarefas e decisões políticas para as quais se deseja independência e neutralidade partidária" (2016, p. 155). Na verdade, o funcionamento ordinário de tribunais constitucionais é dependente da existência de instituições políticas regulares. Tribunais constitucionais não são o "guardião" da Constituição contra as reais ameaças de arbítrio político, pelo contrário, sua existência e autoridade depende de uma ordem constitucional cuja existência é politicamente construída.

Um "guardião" da Constituição, se é possível dispor de tal instituição, deve ser construído a partir de uma relação de "coordenação", não de "subordinação, entre os poderes políticos existentes. No próximo item, apresento a interpretação de Schmitt sobre o presidente do Reich como sendo o "guardião da Constituição" no sistema de Weimar em termos de um modelo de "otimização" do risco político.

\section{O "guardião da Constituição" na Constituição alemã de 1919.}

\footnotetext{
${ }^{8}$ Para uma análise da Suprema Corte estadunidense em como um "police-maker”, uma instituição que, mais que estritamente “jurídica”, é um participante ativo das coalizões políticas dominantes, cf. Robert Dahl (1957).
} 
Der Hüter der Verfassung é uma interpretação das disposições positivas da Constituição alemã de Weimar. Não é uma defesa abstrata e universal de um modelo de controle de constitucionalidade pelo poder executivo, nem uma rejeição taxativa de competências judiciais em tal matéria. Assim, para avaliar as teses de Schmitt sobre o Guardião no sistema de Weimar, é necessário partir de algumas características fundamentais da Constituição então em vigor. São quatro os aspectos mais importantes.

Em primeiro lugar, a Constituição alemã de 1919 não estabelecia expressamente a competência de algum tribunal para declarar a inconstitucionalidade das leis. A afirmação inicial do artigo de 1929, que posteriormente seria revisado e publicado como a primeira parte de Der Hüter der Verfassung, é exatamente essa: "a constituição de Weimar não fala explicitamente de um guardião da constituição" (SCHMITT, 1985, p. 63). O Tribunal do Estado do Reich, previsto no art. 19 da seção 1 da Constituição, destinada às relações entre o Reich e os Länder (Estados), possuía competência expressa para conflitos federativos. No entanto, em 1925 o tribunal do Reich se autoproclamou competente para negar aplicação à legislação ordinária na hipótese de "contradição" com disposição expressa da Constituição, uma prática que foi justificada com fundamento numa interpretação flexível do art. 102, que dispunha: "os juízes são independentes e sujeitos apenas à lei." De acordo com o argumento, "estar subordinado à lei" é uma condição que não exclui a possibilidade de que o juiz negue aplicação à lei nos casos que houver contradição entre essa e outra norma à qual o juiz também está subordinado, como é o caso da Constituição. Nitidamente, é um argumento similar à fundamentação do caso Marbury v. Madison, no qual a Corte Suprema norteamericana se autoproclamou titular de uma competência que, assim como no caso alemão de Weimar, a Constituição não conferia textualmente aos tribunais.

Em segundo lugar, as características específicas do sistema parlamentarista de Weimar. O presidente do Reich era eleito diretamente pelos cidadãos de toda a República, daí seu caráter plebiscitário, ao contrário dos parlamentares, eleitos indiretamente mediante um sistema de listas partidárias. $\mathrm{O}$ chefe do poder executivo era o "chanceler" (o primeiro ministro), que era escolhido mediante indicação pelo Presidente e aprovado pela maioria parlamentar. O parlamento poderia ser dissolvido poder decisão do presidente do Reich. Compare com a definição de "guardião" vista acima: o Presidente do Reich não é um típico "poder", dado que não exerce diretamente, em época de normalidade, a chefia do poder executivo, podendo, portanto, "coordenar" conflitos entre o parlamento e o chefe do poder executivo.

Em terceiro lugar, o presidente possuía amplas competências emergenciais fixadas no artigo 48, fixados em temos muito mais abertos do que ocorre atualmente em constituições contemporâneas:

Art. 48, \$2. Se a segurança pública e a ordem no Reich alemão estiverem significativamente perturbadas ou em perigo, o Presidente do Reich poderá intervir, se necessário, com a ajuda das forças armadas para restaurar a segurança e a ordem pública [...].

Em quarto lugar, por fim, o fato de que o presidente, por juramento exigido constitucionalmente no ato de posse, deveria promover a "proteção da constituição" (art. 42).

Esses quatro aspectos da Constituição de Weimar deveriam fazer com que a tese de Schmitt sobre as competências do presidente da República fossem menos polêmicas do que de fato são. Mesmo os mais ardorosos defensores do controle judicial de constitucionalidade, nas suas mais diversas modalidades, deveriam conceder que, enquanto descrição da constituição então vigente, sua tese era no mínimo plausível.

Nos debates travados por ocasião da Assembleia Constituinte, foi expressamente sugerido por Friedrich Naumann (constitucionalista considerado um dos "fundadores", ao lado de Hugo Preu $\beta$ ) que o presidente deveria funcionar como um remédio institucional para enfrentar "a possibilidade de que, no parlamento 
do Reich, não possa ser encontrada uma maioria e que, por conseguinte, não possa, sem mais, ser formado um governo." (apud SCHMITT, 2016, p. 139). Neste mesmo sentido, Reinhard Mehring (cf. 2014, p. 196) afirma que os fundadores da constituição de Weimar - inclusive Max Weber - temiam uma espécie de absolutismo parlamentarista e pensavam que o parlamentarismo recém-criado precisava de um presidente do Reich dotado de força institucional, um "substituto ao imperador" para contrabalançar a possível fragmentação partidária parlamentar e ausência de governo daí decorrente. Isso confere plausibilidade à interpretação de Schmitt sobre o presidente do Reich como figura central num sistema de instituições destinadas a estabilizar o processo político.

Schmitt não desprezava os riscos inerentes a esse arranjo institucional. Por exemplo, em 1925, afirmou que, graças a esse modelo altamente concentrador de poder no Reichspräsident: "um novo presidente pode mudar completamente a face da constituição de Weimar [...]. Nós podemos dizer que nenhuma outra constituição no planeta torna um coup d'etat legal tão fácil como a constituição de Weimar" (apud MEHRING, p. 196). No entanto, em Der Hüter der Verfassung Schmitt ressalva que, se o parlamento é capaz de "formar uma maioria e agir", ele encontra na Constituição todos os "direitos e possibilidades" para "fazer valer sua vontade perante o presidente e o governo", se impondo com o "fator normativo da volição estatal" (SCHMIT, 2016, p. 131). E se o parlamento não estiver em condições de agir coletivamente? Então ele "não tem o direito de exigir que também todos as outras autoridades responsáveis se tornem incapazes de ação." (SCHMITT, 2016, p. 131). Em última instância, portanto, a responsabilidade por esse problema reside no parlamento, que, sendo incapaz de formar maiorias estáveis capazes de governar, força o presidente a atuar.

Sobretudo a partir de 1929, diante de uma dramática crise política e econômica e da dificuldade de formar maiorias parlamentares capazes de formar um executivo estável, o presidente passou a recorrer cada vez mais aos decretos, com fundamento no art. $48 .{ }^{9}$ No ápice da crise, os partidos que rechaçavam o regime de Weimar - os comunistas do KPD e os nazistas do NSDAP - se uniram para formar uma "maioria negativa" parlamentar: opostos entre si de forma extremada no espectro político, mas capazes de impedir a formação de qualquer governo.

Apenas em 1932, na decisão sobre a intervenção do Reich na Prússia, é que o tribunal afirmou sua autoridade para rever os atos do executivo quanto à decisão de intervenção (embora a decisão em si mesmo não tenha revertido aquela intervenção). Essa decisão foi respeitada pelo presidente, mas isso gerou a consequência de dificultar a continuidade do governo por decreto presidencial. Assim, a consequência indireta da expansão do controle judicial sobre os poderes presidenciais foi tornar impossível a continuidade de um governo presidencial extraordinário sem maioria parlamentar, o que naquele contexto impunha ao presidente as alternativas de uma negociação parlamentar com o NSDAP para formar uma maioria parlamentar ou convocar novas eleições, assumindo o risco de um crescimento do peso do NSDAP.

Em 1958, no posfácio a uma nova edição de Legalidade e Legitimidade (2004), Schmitt afirmou que aquele seu ensaio, publicado no contexto da crise de 1932-33, era "uma tentativa desesperada de salvaguardar a última esperança da Constituição de Weimar, o sistema presidencial, frente a uma forma de teoria jurídica recusava a enfrentar a questão do amigo e inimigo da Constituição." (SCHMITT, 2004, p. 95). No caso, o "inimigo" da Constituição era representado pela "maioria negativa" formada pelos partidos extremistas anti-Weimar, o KPD e o NSDAP, que juntos inviabilizavam a formação de um executivo estável, uma situação insustentável no contexto de dramática crise econômica, social e política. Essa afirmação é coerente com sua intervenção pessoal nos instantes finais da crise que pôs fim ao regime de Weimar,

\footnotetext{
9"Por razões práticas, até os social-democratas concordaram em tolerar o questionável governo por decreto, até que o Reichstag fosse novamente capaz de funcionar. Como pensavam republicanos como Thoma e Walter Jellinek, se o Reichstag não era capaz de agir, então a segunda metade do sistema constitucional democrático, o presidente e o gabinete, tinham que assumir poderes mais amplos até que a crise fosse superada." (CALDWELL, 1997, p. 109).
} 
quando demonstrou apoio e buscou influenciar o plano do conservador Kurt von Schleicher, o ultimo chanceler alemão antes de Hitler, que visava impedir a indicação de Hitler à chancelaria, o que incluía a decretação de emergência constitucional, a dissolução do parlamento, o adiamento das eleições e um governo por decreto presidencial. ${ }^{10}$ É por isso que Schmitt vincula a indicação de Hitler à chancelaria - e a consequente derrocada do regime - a uma "falsa concepção de legalidade", segundo a qual o tribunal é competente para rever questões essencialmente políticas, como a edição dos decretos presidenciais do art. 48 em situação de emergência ${ }^{11}$ : "nos dias decisivos antes de 30 de janeiro, o governo do Reich capitulou com um falso conceito de legalidade e a ameaça de novos julgamentos perante o Staatsgerihshof se tornou uma arma jurídica eficaz" (2004, p. 101). A expansão da atuação do tribunal para o domínio dos conflitos políticos não gerou mais "efetividade da Constituição", mas sim colaborou para acelerar a crise final da república de Weimar (cf MEHRING, p. 265).

Para uma perspectiva essencialmente "precaucionária" isso pode parecer um "paradoxo". Afinal, quanto maior a possibilidade de submissão da "política" (sobretudo do poder executivo) à jurisdição constitucional, maior a efetividade constitucional. Mas Schmitt rejeita essa concepção "equivocada de legalidade", com argumentos que poderiam equipará-la ao que Vermeule denominou "constitucionalismo de precaução". Ao final, o equívoco da concepção é que ela impede ou ao menos dificulta que, em meio a uma crise institucional de gigantescas proporções, a principal função de uma Constituição seja desempenhada: "é o sentido de qualquer constituição sensata que permita a formação de um estado e de um governo capaz de governar." (SCHMITT, 2016, p. 115). Esse é um típico "argumento de perversidade”: um poder executivo "precaucionariamente" enfraquecido, com o objetivo de reduzir ao máximo o risco político, pode promover exatamente o malefício que se buscava coibir, estimulando ações governamentais à margem da Constituição. A adoção excessiva de disposições constitucionais que impedem o poder executivo de agir com vigor, longe de evitar o arbítrio político enfraquecendo o poder presidencial, pode estimular exatamente o oposto, a ruptura institucional. ${ }^{12}$ No contexto de Weimar, a defesa da ordem constitucional (e não de disposições particulares da constituição) exigia enfrentar os partidos extremistas (NSDAP e KPD) e permitir a formação de um governo capaz de atuar, algo muito além das capacidades políticas dos tribunais ordinários. Seria ingênuo imaginar que, naquele contexto, a existência de uma corte constitucional forneceria meios eficazes para cumprir uma tal tarefa.

Ulrich Preuß (2016) tem razão quando afirma ser uma "ingenuidade" considerar Schmitt (com base nos argumentos algo indulgentes apresentados no posfácio de 1958) um "apaixonado defensor da constituição de Weimar". De fato, são bastante conhecidas as críticas de Schmitt a aspectos centrais daquele regime, como por exemplo a fragmentação partidária parlamentar e - um dos temas centrais de Legalidade e Legitimidade - a ausência de limites materiais expressos ao poder de reformar a constituição

10"Quando Schleicher fez uma tentativa final de implementar o plano do estado de emergência, impedindo assim a nomeação de Hilter, Schmitt tentou convencê-lo (...) a escolher uma maneira de agir juridicamente menos controversa - ou seja, a não aceitação de um voto sem confiança e confirmação de seu governo pelo Reichspräsident” (MEHRING, 2014, pp. 270-271). Schmitt pretendia com isso reduzir as resistências do presidente Hindenburg. A proposta de Schleicher, "provavelmente a última chance de sobrevivência de Weimar" (MEHRING, 2014, 271), foi amplamente rejeitada por todos os partidos. A influência de Schmitt como assessor jurídico antes do segundo semestre de 1932 era pequena, embora seja superdimensionada em algumas interpretações (Cf. MEHRING, 2014, p. 252)

${ }^{11}$ Voltaremos a esse ponto nos itens 5 e 6 adiante.

${ }^{12}$ Vermeule (2014) ilustra sua tese citando a passagem de Madison e Hamilton em “O Federalista” $\mathrm{n}^{\circ} 20$ : Uma Constituição fraca tem necessariamente que terminar em dissolução, por falta dos poderes adequados, ou na usurpação de poderes indispensáveis para a segurança pública. Que a usurpação, uma vez começada, se detenha no ponto salutar, ou prossiga até o extremo perigoso, deve depender das contingências do momento. A tirania originou-se talvez com maior frequência por ser assumido o poder por alguém a quem se apelou, diante de exigências prementes e por causa de uma Constituição deficiente, do que por serem exercidos plenamente os mais amplos poderes constitucionais. (HAMILTON, MADISON, JAY, 2011, p. 205) 
por supermaioria parlamentar. No entanto, é equivocado afirmar que as teses de Schmitt em Der Hüter der Verfassung são precursoras do totalitarismo pós-1933, apresentando como "prova" de tal conclusão o fato de que Schmitt acredita que ser o presidente do Reich titular de competências excepcionais atribuídas pela constituição alemã de 1919. ${ }^{13}$ Aliás, a percepção de que a fragmentação parlamentar e a instabilidade do executivo resultantes do desenho institucional da constituição de Weimar foram determinantes para a crise de 1933 foram amplamente compartilhadas pelos redatores da atual constituição alemã, a Lei Fundamental de Bonn (1949). ${ }^{14}$ Igualmente equivocado é afirmar que textos redigidos no período nazi, quando a Constituição de Weimar não se encontrava mais em vigor, são o desenvolvimento teórico das teses do texto de $1931^{15}$. Em outras oportunidades, a participação pessoal de Schmitt no criminoso regime nazista entre 1933 e 1936, é utilizada para desqualificar (de forma aberta ou velada) as teses do livro publicado em 1931, numa espécie de variação da falácia reductio ad Hitlerum ${ }^{16}$.

Enfim, a afirmação de Schmitt de que o presidente do Reich é o guardião da Constituição no regime de Weimar pretende ser uma descrição das normas positivas de um sistema constitucional específico, não uma prescrição de caráter universal, válida para todo e qualquer sistema constitucional ${ }^{17}$. Mas para realizar essa descrição, ele se apoia numa perspectiva dos conflitos políticos constitucionais essencialmente "otimizante", produzindo lições cuja utilidade ultrapassa aquele contexto particular. Nos itens 4 e 5 a seguir, discutirei duas dessas teses, para no item 6 aplicá-las ao debate sobre o status do STF como "guardião" da Constituição brasileira de 1988.

\section{Separação e poderes e autorestrição judicial.}

Como foi dito acima, a Constituição de Weimar não previa expressamente a competência dos tribunais para o exercício do controle judicial de constitucionalidade da legislação, mas os tribunais alemães passaram a exercer o controle incidental de constitucionalidade com argumentos similares aos utilizados no caso Marbury versus Madison. Essa competência foi exercida de modo bastante autocontido, o que é exemplificado pelo fundamento de uma decisão de 1930 do Staatsgerichtshof, que Schmitt cita expressamente, concordando, segundo a qual o Tribunal "só pode obstar às decisões do legislador, se é que pode, se carecerem claramente da justificativa interna e se delas se puder dizer, assim, com segurança que contrariam a vontade do legislador constitucional.” (apud 2016, p. 52).

Schmitt endossa a postura de autocontenção do tribunal no exercício do exame material de constitucionalidade, justificando tal competência na idéia de separação de poderes. Sua posição é representativa de um princípio bastante convencional de interpretação constitucional, com sólido amparo doutrinário

\footnotetext{
${ }^{13}$ Exemplar é a interpretação de Caldwell (1997), para quem Schmitt meramente abriu as portas para a eventual tomada nazista do poder”. (p. 119).

${ }^{14}$ Isso é nítido da adoção de um sistema eleitoral com aspectos majoritários, incluindo cláusulas de desempenho para que os partidos possam ingressar no parlamento. Além disso, o processo de escolha e substituição do chefe do chanceler confere maior estabilidade ao governo.

${ }^{15}$ Mesmo uma cuidadosa análise da obra de Schmitt, como a realizada por Ronaldo Porto Macedo Jr. (2011) parece sugerir isso ao afirmar que "Em 'O defensor da Constituição' [...], Schmitt desenvolve a tese segundo a qual o Führer deve ser o verdadeiro guardião da Constituição. [...] Num texto de 1934, 'O Führer protege o Direito', Schmitt radicaliza tal ideia [...]” (p. 55). O simples uso da expressão "Führer", do texto de 1934, para analisar a interpretação do texto de 1931 sobre o "Reichpräsident" é um equívoco que deve ser evitado.

16“[...] devemos evitar a falácia que nas últimas décadas tem sido frequentemente usada como um substituto da reductio ad absurdum: a reductio ad Hitlerum. Uma concepção não é refutada pelo fato de ela ter sido partilhada por Hitler." (STRAUS, 2014, p. 52)

${ }^{17}$ Por isso discordo da tese de Kalyvas (2008), para quem a afirmação de Schmitt quanto ao presidente do Reich é um modelo normativo que ultrapassa o contexto particular da constituição de Weimar: "Em uma constituição democrática, afirmou Schmitt, o papel do guardião deveria ser concedido a um presidente eleito democraticamente. Nem um tribunal supremo ou constitucional nem o parlamento podem desempenhar esse papel." (KALYVAS, 2008, p. 156).
} 
e jurisprudencial: a não ser que a afronta à norma constitucional seja expressa, acima da dúvida razoável, haverá uma interferência indevida dos tribunais no âmbito da política legislativa. Afinal, o controle de constitucionalidade é uma competência institucional que também pode afrontar a constituição, caso não seja exercido com considerável auto-restrição. Essa postura de autorestrição judicial e deferência aos juízos políticos legislativos no exercício do judicial review é o tema do clássico artigo de James Bradley Thayer, The Origin and Scope of the American Doctrine of Constitutional Law (1893), que extrai da jurisprudencia norte-americana diversas manifestações em defesa desse princípio: "um ato da legislatura não deve ser declarado nulo a menos que a violação da Constituição seja tão manifesta que não deixe espaço à dúvida razoável” (William Tilghman, em 1811, apud THAYER, 1893, p. 140). Essa é coerente com a própria definição de "Guardião", que como foi visto acima, envolve a capacidade de enfrentar divergências políticas que, por sua natureza, "não podem ser decididas, no geral, judicialmente, caso não seja exatamente o caso de punição por violações constitucionais abertas.” (SCHMIT, 2016, p. 132). Ou seja, na hipótese de flagrante e radical violação, há margem para sua resolução judicial.

Schmitt afirma que uma decisão judicial que nega aplicação a alguma lei por suposta ofensa a "princípios constitucionais" abstratos não pode ser considerada um típico exercício da jurisdição, mas um ato de política legislativa. $\mathrm{O}$ fato é que quando um tribunal nega aplicação a uma lei ordinária sob o fundamento de que ela "afronta" a concepção (considerada pelo juiz) de algum princípio constitucional abstrato ("dignidade humana", por exemplo), apenas formalmente - e com alguma ingenuidade - um tal ato pode ser considerado "interpretação" ou "efetivação" do direito constitucional pré-existente. Trata-se, na verdade, de um ato de "decisão", de "escolha", sobre qual deve ser o melhor e mais adequado significado do princípio abstrato. É "legislação constitucional”, portanto: "Toda instância que resolve um conteúdo jurídico duvidoso atua como um legislador sobre o assunto. Se colocar o conteúdo duvidoso de uma lei constitucional fora da dúvida, ele age como um legislador constitucional." (SCHMITT, 2016, p. 45). Mais uma vez, Schmitt expressa um argumento a favor da autorestrição judicial: apenas diante de contradição flagrante os tribunais devem negar aplicação às leis, do contrário - se revisam a legislação com fundamento em princípios controvertidos - estarão agindo como legisladores, não juízes. É um posicionamento convencional, já amplamente registrado na jurisprudência norte-americana, por exemplo Thomas Charlton, em 1808:

Essa violação de um direito constitucional deve ser tão óbvia para a compreensão de todos quanto uma verdade axiomática (...). O judiciário seria autorizado, sem hesitação, a declarar inconstitucional a lei. Mas quando permanece duvidoso que o legislador tenha ou não invadido a constituição, um conflito deve ser evitado, porque existe uma possibilidade de, nesse caso, a Constituição estar ao lado do legislador. (apud THAYER, 1893, p. 141)

Ao analisar o exercício do controle incidental de constitucionalidade pelos tribunais (o exame material de constitucionalidade), Schmitté insistente quanto à existência de uma alternativa taxativa e excludente: ou tribunais se limitam a negar aplicação a leis em casos de flagrante contradição de algum dispositivo expresso na Constituição, ou os tribunais estarão praticando um ato de legislação constitucional, sob a forma de sentença judicial.

[...] ou há uma violação óbvia, indiscutivelmente detectável, da constituição, e a Corte exerce um tipo de judiciário repressivo e vingativo [...] ou o caso é incerto e duvidoso, seja por razões de fato, seja devido à incompletude e amplitude necessárias de cada constituição escrita em geral ou à peculiaridade da segunda parte principal da constituição de Weimar em particular, não haverá "questão legal pura" e a decisão o tribunal de justiça é diferente de uma decisão judicial, algo diferente de justiça. (2016, p. 31-32)

Sempre resulta a mesma e óbvia alternativa: ou existe uma contradição óbvia e inquestionável às disposições constitucionais, então o Tribunal pune essa violação, [...]; ou as dúvidas sobre o conteúdo de uma norma são tão justificadas e o conteúdo da norma em si não é tão claro que não pode ser afirmado que há violação, mesmo que o tribunal tenha uma opinião diferente da legislatura ou do governo, cujas ordens estão em conflito com o direito constitucional dúbio. (2016, p. 45) 
[...] ou é obviamente uma violação inquestionável da constituição [...]; ou é caso de dúvida, e então a área de justiça é limitada a nada, [...] porque uma presunção geral fala pela validade dos arquivos legislativos e governamentais [...]. (2016, p. 50)

De um lado, típico exercício da jurisdição ordinária, aplicando direito pré-existente a casos concretos. De outro, opção política, escolha, decisão entre alternativas igualmente constitucionais, prática essencialmente legislativa. Essa distinção é apresentada como um corolário da própria idéia de Estado de Direito: "não há Estado de Direito sem uma justiça independente, não há justiça independente sem vinculação material a uma lei e não há vinculação material à lei sem diversidade objetiva entre lei e sentença judicial" (SCHMITT, 2016, p. 36). A independência judicial é uma exigência de um Estado de Direito, mas essa independência não confere ao poder judiciário competências políticas legislativas, como se fosse ele um pequeno Estado soberano ao lado de outros poderes. O judiciário é independente, mas subordinado à constituição, a qual não lhe confere competências de legislador soberano; é independente para julgar nos casos concretos, mas subordinado - "vinculado materialmente" - à legislação que resulta de uma prévia decisão política por instâncias representativas; é independente, mas para julgar de acordo com as leis, não para impor as leis de sua preferência. Daí a necessidade de preservar a "diversidade objetiva entre lei e sentença judicial". E essa distinção é abolida se, por ocasião do exercício do exame material de constitucionalidade, os tribunais deixam de aplicar legislação ordinária em benefício de alguma opção política particular construída a partir de algum princípio constitucional abstrato e totalmente dependente da vontade e opinião do intérprete.

[...] subsunções determináveis e mensuráveis que permitem padrões devem formar a base da revisão e decisão judicial. A ligação a essa norma também é o pré-requisito e condição de toda independência judicial. Se o juiz deixar o terreno em que realmente existe uma subsunção substantiva e, portanto, um vínculo substantivo com a lei, ele não poderá mais ser um juiz independente, e nenhuma aparência de justiça poderá impedir essa conclusão". (SCHMITT, 2016, p. 19)

A forma taxativa como Schmitt apresenta a alternativa "ou interpretação literal, ou legislação" resulta de sua correta compreensão da natureza especificamente política do controle de constitucionalidade, por oposição ao típico exercício da jurisdição. Essa distinção entre jurisdições pode ser demonstrada por meio de um exemplo envolvendo o art. 1228, $\$ 4^{\circ}$, do Código Civil. ${ }^{18}$ Um primeiro tipo de controvérsia surge no âmbito de um processo judicial no qual se discute a reintegração de posse: no caso concreto, a solução da controvérsia passa a depender da decisão do magistrado sobre o concreto significado de duas expressões: "considerável número de pessoas" e "interesse social e econômico relevante". É fácil perceber que qualquer decisão sobre a matéria dificilmente poderá resultar da simples aplicação de postulados normativos capazes de fornecer alguma orientação segura. A decisão será o resultado de uma percepção individual do magistrado, inevitavelmente vinculada às suas opiniões sobre os critérios capazes de auferir a relevância "social e econômica" das obras e serviços no local realizadas ${ }^{19}$. E magistrados apoiados em convicções "liberais" ou "socialistas" interpretarão o dispositivo de forma previsivelmente distinta. Mas ainda assim, não há dúvida quanto ao fato de que a lei aplicável à matéria não apenas permite, mas exige, que o juiz realize a avalição da existência ou não, no caso concreto, desses requisitos. No entanto, o juiz ou tribunal que decide o caso pode ocupar a posição de um "terceiro imparcial", sem interesse ou vinculação pessoal com a matéria. ${ }^{20}$

\footnotetext{
${ }^{18}$ Código Civil, art. 1.228, $\$ 4^{\circ}$. O proprietário também pode ser privado da coisa se o imóvel reivindicado consistir em extensa área, na posse ininterrupta e de boa-fé, por mais de cinco anos, de considerável número de pessoas, e estas nela houverem realizado, em conjunto ou separadamente, obras e serviços considerados pelo juiz de interesse social e econômico relevante. (grifei)

19“Os conceitos abertos existentes no art. 1.228 do CC/2002 propiciam ao magistrado uma margem considerável de discricionariedade ao analisar os requisitos para a aplicação do referido instituto [...]”. (STJ, 2018). Agradeço ao professor Guilherme H. L. Heinig a sugestão deste julgado.

20“A posição especial do juiz no Estado de Direito, sua objetividade, sua posição sobre as partes, sua independência e inamovibilidade, tudo isso se baseia no fato de que ele apenas decide com base em uma lei e sua decisão se baseia em outra, mensurável e previsível, contida e derivada da lei”. (2016, p. 37-38)
} 
Compare agora com um caso hipotético: o Supremo Tribunal Federal examina a constitucionalidade do $₫ 4^{\circ}$ do art. 1228 do Código Civil, avaliando eventual afronta ao disposto na CF/88, art. 5, XXII: "é garantido o direito de propriedade." Ao final, por maioria de $6 \times 5$, prevalece no tribunal a tese de que o dispositivo legislativo que autoriza um juiz a privar o proprietário de seu imóvel é uma evidente afronta ao Direito fundamental à propriedade privada. Em ambos casos, juízes decidem com base em alguma convicção política - ao menos implícita. E algum efeito político sempre resultará das decisões, em virtude da redistribuição da propriedade privada entre os membros da comunidade. Mas a diferença é crucial. No primeiro caso, de jurisdição ordinária, magistrados e tribunais proferem sentença (controvertida) apoiados em expressa decisão política anterior tomada no âmbito do processo legislativo representativo: 0 Código Civil. E se eventualmente as seguidas aplicações judiciais do dispositivo despertarem a percepção pública de que uma tal prática judicial produz mais malefícios que benefícios, o mesmo poder legislativo representativo pode revogar a lei ou alterar sua redação, aprimorando-a. Daí que mesmo diante das infindáveis controvérsias que atingem a interpretação do art. 1228 do CC, o juiz ainda poderá atuar como um "terceiro imparcial” na decisão do caso. Trata-se aqui da

Neutralidade no sentido de objetividade e objetividade com base em uma norma reconhecida. Esta é a neutralidade
do juiz, desde que ele decida com base em uma lei reconhecida e determinável. [...] Essa neutralidade leva uma
decisão, mas não a uma decisão política" (SCHMIT, 2016, p. 114).

Já no segundo caso, de jurisdição constitucional, um tribunal revisa a decisão política legislativa, decidindo revogá-la com fundamento na opinião (que a maioria da corte entende ser a correta) sobre o significado da expressão "direito de propriedade". Embora proferida por um tribunal no âmbito de um processo judicial, trata-se nitidamente de uma decisão de natureza geral e abstrata sobre qual norma deve vigorar sobre toda a comunidade. É neste sentido que devemos entender a afirmação de que "toda justiça (justiz) está vinculada a normas e termina quando o conteúdo das próprias normas se torna duvidoso e controverso" (SCHMITT, 2016, p. 18).

Além disso, ao declarar a inconstitucionalidade do dispositivo do código civil o tribunal não atua institucionalmente falando - como um "terceiro imparcial". Afinal, toda instituição que decide de forma inapelável sobre alguma matéria politicamente controvertida, proferindo a "última palavra" sobre a validade de uma norma, decide politicamente. Quando um tribunal decide se o poder legislativo exorbitou de suas competências políticas está decidindo simultaneamente sobre (1) os limites do poder legislativo (2) sua própria competência - do tribunal - para avaliar o desempenho dos demais poderes (Cf. WALDRON, 2016, pp. 195-245). Enfim, no exercício do controle judicial de constitucionalidade, inevitavelmente a corte "julga em causa própria", sobre seus próprios limites para fiscalizar as demais instituições. E se é assim, na decisão proferida em sede de controle judicial de constitucionalidade, pelo seu caráter políticolegislativo (estabelece a norma geral e abstrata em vigor) e parcial (o próprio tribunal avalia quais são seus limites, julgando em seu próprio benefício, institucionalmente falando), uma tal decisão carece da figura do "terceiro imparcial", essencial para um processo tipicamente judicial.

É um caso que exemplifica aquilo que Jeremy Waldron denomina "as circunstâncias da política": "a discordância entre os cidadãos quanto ao que devem fazer, como corpo político" acrescida da "necessidade sentida de agir conjuntamente, embora discordemos quanto ao que fazer" (WALDRON, 2003, p. 187). Em nosso caso, os membros da comunidade simultaneamente (1) divergem irremediavelmente sobre "o que fazer" em relação à proteção da propriedade privada e à exigência de que a propriedade cumpra sua "função social", e (2) desejam estabelecer um critério de "ação" que seja válido para toda a comunidade. $\mathrm{O}$ art. 1228, $\$ 4^{\circ}$, do CC, exemplifica exatamente um tipo de decisão política com a qual representantes da comunidade buscam estabelecer critérios, gerais e abstratos, de cooperação. Por isso, se um tribunal é provocado a avaliar a constitucionalidade desse artigo, ele deve se limitar a verificar se o mesmo afronta expressamente algum dispositivo constitucional, ao invés de investir em "construções" interpretativas 
sobre o significado de princípios abstratos. Por isso, no exercício da jurisdição constitucional, "a questão essencial não é qual é o verdadeiro significado da Constituição, mas se a legislação é sustentável ou não" (THAYER, 1893, P. 150).

É por isso que Hans Kelsen, quando critica a distinção schmittiana entre "interpretação" e "legislação", se equivoca. Ele basicamente insiste no fato de que é normal que, no exercício da jurisdição, a decisão judicial será inevitavelmente "criativa" em algum grau, dado que a diferença entre interpretação e legislação é apenas de "grau", não de "natureza". Em outras palavras, segundo Kelsen, o juiz deve também "decidir" e "criar", preenchendo uma moldura normativa que the foi delegada pelo legislador (KELSEN, 2003, pp. 250 e ss). Mas Schmitt não ignora o fato de que, no exercício da jurisdição, algum grau de "criação" de Direito pela via da decisão judicial é inevitável. Esse é, aliás, o tema de um de suas primeiras obras, de 1912, Gezets und Urteil (Lei e Juizo), um "exame sobre o problema da práxis judicial" (Cf. SCHMITT, 2012, pp. 5 e ss). ${ }^{21} \mathrm{O}$ problema é que, politicamente, é inteiramente diferente afirmar a "criatividade judicial" no âmbito da aplicação da legislação infraconstitucional, como no caso do art. $1228, \mathbb{\$} 4^{\circ}$, do CC/02, e a "criatividade judicial" no exercício da jurisdição constitucional, interpretando diretamente disposições constitucionais como o inciso XXII, do art. $5^{\circ}$, da CF/88. No primeiro caso, a "legislação" judicial pode ser eventualmente contida ou inviabilizada mediante decisão do poder legislativo, revendo a autorização conferida através dispositivo do Código Civil. No segundo caso, um tribunal estará livre para "legislar" sem possibilidade de revisão por instituições politicamente representativas. Este ponto será desenvolvido nos próximos dois itens.

\title{
5. Judicialização da política, politização da justiça.
}

Em Der Hüter der Verfassung Schmitt desenvolveu uma crítica à expansão das competências políticas dos tribunais, apontando o risco de surgimento de uma "Aristokratie der Robe" (2016, p. 156), uma aristocracia da toga, um aristocrático "governo de juízes".2 Seus argumentos podem ser compreendidos como casos típicos de "futilidade" e "perversidade", no sentido que Adrian Vermeule confere a essas expressões. Já em Verfassunglehre (2003), Teoria da Constituição, cuja primeira edição é de 1927, comentando algumas das propostas de reforma da Constituição de Weimar para criação de um Tribunal constitucional, ele afirma: "Separar aqui as questões jurídicas das políticas e pensar que um assunto jurídico-político pode despolitizar-se, seria uma ficção confusa” (p. 118). E a seguir critica os argumentos de Gerhard Anschütz, talvez o principal comentarista da Constituição de Weimar:

\begin{abstract}
[Ele] quer que se transfira a um Tribunal de Estado para o Reich alemão a decisão de todos os litígios sobre interpretação e aplicação da Constituição do Reich, mas lhe parece uma "coisa clara" que o Tribunal haveria de decidir somente questões jurídicas, em contraposição às questões políticas. "Não creio - diz ele - que neste ponto se deva observar alguma outra coisa”. Temo que, pelo contrário, a questão comece neste ponto. Por isso, ao invés de um tribunal com sua aparência de formas judiciais, decide com mais dignidade uma instancia política, algo como um "Senado", ao modo das Constituições napoleônicas, que previam um chamado Sénat conservateur para a defesa da Constituição (...). Se não, existe o perigo de que, ao invés de levar o Direito à política, se leve a política à justiça, corroendo sua autoridade. (SCHMITT, 2003, 118-119) (Grifei)
\end{abstract}

Schmitt desenvolve essa idéia em Der Hüter der Verfassung, identificando e rejeitando "uma idéia abstrata e incompreendida do Estado de Direito" que nos impele a equivocadamente considerar como

\footnotetext{
${ }^{21}$ Para uma defesa da posição kelseniana neste debate, cf. especialmente José Lamego (2019, pp. 196-199); Stanley Paulson (2016, pp. 510-546. Para uma interessante crítica ao instituto do controle judicial de constitucionalidade, aproximando as teses de Carl Schmitt e Jürgen Habermas quanto a esse ponto, cf. Delamar Volpato Dutra (2018, p. 15).

${ }^{22}$ Ran Hirschl(2004) utiliza expressão similar para criticar a judicialização da política levada a cabo pelo constitucionalismo contemporâneo em seu Towards Juristocracy: the origins and consequences of the new constitutionalism.
} 
[...] natural conceber a resolução judicial de todas as questões políticas como um ideal do estado de direito e ignorar o fato de que, se o judiciário se expandir para um assunto que não pode mais ser judicial, o judiciário só poderá ser prejudicado. Porque (...) o resultado não seria uma juridificação da política, mas uma politização do judiciário. (SCHMIT, 2016, p. 22)

Essa "ideia abstrata e incompreendida de Estado de Direito" é amplamente predominante na teoria constitucional contemporânea, sobretudo se observarmos as versões mais idealizadas do princípio da "supremacia da constituição", para as quais a "Constituição jurídica subordina a política ao Direito" (SAJÒ; UITZ, 2017, p. 23). Trata-se de um desenvolvimento do clássico ideal de um "governo das leis", por oposição a um arbitrário "governo dos homens": um Estado no qual as decisões e competências dos agentes políticos estão subordinadas à autoridade de uma Constituição plenamente vinculante. Em termos mais exigentes, essa ideia pode ser expressa em termos de uma afirmação da "soberania da Constituição", característica de um Estado materialmente efetivamente constitucional: "no Estado Constitucional há somente competências delimitadas pelo Direito Constitucional vigente." (KRIELE, 2009, p. 179). De acordo com tal concepção, não existe qualquer autoridade que possa ser considerada soberana, exceto a própria Constituição: “Se há algum soberano, é a Constituição." (Cf. BÖCKENFÖRDE, 2017, p. 143 e ss.). Isso implica que todo poder político, todo órgão ou instituição, encontra-se abaixo da Constituição. Isso se aplica não apenas aos órgãos dos poderes legislativo e executivo, mas mesmo à autoridade do "povo", definido como um órgão dotado de procedimentos e competências específicas (plebiscitos, referendos, eleições etc). Assim, "cada tipo de ação estatal [...] deve estar vinculada retroativamente à constituição. Ele exige uma cobertura constitucional que autorize ou pelo menos permita essa ação." (BÖCKENFÖRDE, 2017, p. 143).

No caso brasileiro, tais crenças eram compartilhadas por boa parte dos membros da Assembléia Nacional Constituinte e influenciaram a adoção de um sistema de controle de constitucionalidade tipicamente "precaucionário" na Constituição de 1988: muitos agentes com poder de ingressar com ações de controle concentrado; diversas ações que permitem revisar judicialmente inclusive a omissão legislativa; competências "difusas" de controle, para todo o poder judiciário. ${ }^{23}$ Enfim, a intenção da assembleia nacional constituinte parece ter sido a de criar um sistema "robusto e redundante", sob o fundamento aparente de que quanto mais instituições e procedimentos judiciais com poder de revisar os atos políticos legislativos e administrativos, mais a efetividade da constituição estaria garantida. O princípio que orientou a adoção do modelo de controle de constitucionalidade atualmente em vigor no Brasil parece ter sido "mais controle judicial gera maior efetividade constitucional". A natureza precaucionaria da concepção é evidente: pretende enfrentar o risco de arbitrariedade submetendo as questões políticas à autoridade judicial, de modo que as decisões possam ser revistas no âmbito de um criterioso procedimento jurisdicional, com partes que se enfrentam argumentativamente, arbitradas por um terceiro imparcial responsável por fazer valer a Constituição. Essa pretensão é levada ao extremo em certas defesas da autoridade de tribunais constitucionais, que conferem às cortes uma legitimidade para "representar o povo" de uma forma "purificada". Um exemplo é a tese de Robert Alexy (2015, p. 53-54):

O princípio fundamental: "Todo poder estatal origina-se do povo" exige compreender não só o parlamento, mas também o tribunal constitucional como representação do povo. A representação ocorre, decerto, de modo diferente. $O$ parlamento representa o cidadão politicamente, o tribunal argumentativamente.

De um lado, a política, com seus conhecidos vícios; de outro, o "discurso racional”. Porém, com Schmitt e contra Alexy, é possível objetar que "é um truque especificamente político apresentar a própria visão como apolítica e colocar as perguntas e opiniões do oponente como políticas." (SCHMIT, 2016, p. 3). E nisso consiste o "formalismo" dessa compreensão do Estado de Direito: a tentativa de justificar de

\footnotetext{
${ }^{23}$ Para uma análise dos conflitos interpretativos resultantes de nosso complexo sistema de controle da administração pública, cf. SOARES (2017).
} 
modo artificial a expansão da autoridade judicial para decidir sobre matérias essencialmente políticas. Pretende-se com isso conferir caráter "judicial" às decisões políticas simplesmente em virtude do fato de que tais decisões são agora tomadas por tribunais. Pretende-se assim ocultar a natureza do problema de um modo puramente conceitual: o "Direito" é artificialmente equiparado à "justiça” (Justiz); a seguir, "justiça" é tudo aquilo que é feito por uma autoridade judicial. Com isso, decisões essencialmente políticas podem ser praticadas por agentes que integram tribunais ao mesmo tempo que reivindicam para tal atividade o status de "aplicação do direito". (Cf. 2016, p. 38). Esse "formalismo" está presente também no controle incidental de constitucionalidade com base em princípios abstratos: toda decisão tomada por um magistrado no âmbito de um processo judicial é, em decorrência desse simples fato formal, definida como típico exercício da jurisdição; e sendo exercício da jurisdição, princípios constitucionais abstratos estão sendo aplicados ao caso concreto. No entanto, essa expansão da justiça para domínios essencialmente políticos não altera a natureza do conflito. Pelo contrário, as matérias permanecem políticas, só que agora objeto de decisão pela "justiça”:

Nenhuma formalidade judicial poderia esconder o fato de que tal Tribunal do Estado ou constitucional seria uma instituição altamente política com poderes constitucionais. Do ponto de vista democrático, dificilmente seria possível transferir essas funções para uma aristocracia da toga. (2016, p. 155-56).

Esse é um argumento recorrente em Schmitt: a judicialização da política corresponde a uma tentativa de "despolitização". No entanto, no máximo ela elimina um tipo de política, a política partidária pois:

\begin{abstract}
[...] a política é inevitável e impossível de erradicar. [...] a peculiaridade da política reside no fato de que toda área concebível da atividade humana pode ser política e imediatamente se torna política quando surgem conflitos e questões decisivas nessa área. Portanto, é um equívoco e uma frase enganosa, se não fraudulenta, sugerir que a despolitização significa que a responsabilidade e o risco inconvenientes da política podem ser evitados e erradicados. Tudo o que é de alguma forma de interesse público é de alguma forma político, e nada que diga respeito essencialmente ao Estado pode ser seriamente despolitizado. (2016, p. 111).
\end{abstract}

As tentativas de "despolitização" pela via da expansão das competências judiciais, além de manter o risco de arbitrariedade existente em toda decisão política, acrescenta riscos adicionais. Graças a essa expansão, "o Guardião torna-se facilmente senhor da Constituição e surge o perigo de um duplo chefe de Estado" e com isso também "um órgão inamovível, irresponsável e que decide à sua discrição." (SCHMITT, 2016, p. 7). Aqui Schmitt apresenta um típico argumento de "perversidade": no objetivo de "minimizar" o risco de arbitrariedade política (das instituições explicitamente políticas, o legislativo e o executivo) a "maximização precaucionaria" do controle judicial criou as condições para que praticamente qualquer assunto politicamente relevante possa ensejar alguma espécie de revisão judicial. Com isso, o risco de arbitrariedade política não foi anulado, mas transferido de instituição e potencialmente ampliado. ${ }^{24}$

\title{
6. O STF é o guardião da Constituição de 1988?
}

Poderíamos extrair alguma lição de Carl Schmitt que seja útil ao debate sobre o "guardião" da Constituição brasileira de 1988? À primeira vista, seria possível questionar a própria existência de um “debate”, posto que nossa Constituição expressamente estabelece que "compete ao Supremo Tribunal Federal, precipuamente, a guarda da Constituição" (art. 102). A despeito de qualquer valor teórico-abstrato das teses de Carl Schmitt, essa disposição expressa do texto não deveria encerrar qualquer dúvida estritamente dogmática? O posicionamento amplamente majoritário em nossa doutrina constitucional certamente entende que

\footnotetext{
${ }^{24}$ Benjamin Schupmann (2017), comentando as teses de Hüter der Verfassung, afirma que "a marginalização do judiciário em sua teoria é decepcionante por que ela parece ser uma solução alternativa plausível aos perigos do abuso de poder pelo legislativo ou pelo executivo quando as relações de balanceamento entre esses poderes se tornaram disfuncionais." (SCHUPMANN, 2017, p. 171) É difícil entender de que modo a rejeição de Schmitt à expansão das competências judiciais possa ser considerada "decepcionante", pois, certa ou errada, essa rejeição é coerente com o diagnóstico realizado por Schmitt. Não pode haver "decepção" se ele não sugeriu conclusão distinta.
} 
sim. E não se trata apenas das análises estritamente doutrinárias. A imagem de um "STF guardião da Constituição" parece ser amplamente dominante na opinião pública de modo geral. Por exemplo, em uma excelente análise, realista e rigorosa, sobre a atuação do STF nas últimas décadas, é possível ler:

O Supremo Tribunal Federal foi alçado a guardião da Constituição pela política para preservar de ataques circunstanciais o pacto social firmado pós-ditadura. Combater o STF é atacar a Constituição de 1988. Ameaçar o Supremo é um comportamento autocrático, um primeiro sinal do desejo de quem quer governar sem democracia. Esvaziar o tribunal é comprometer o sistema de garantias e direitos individuais. (RECONDO e WEBER, 2019, p. 26)

São muitos os postulados dados como óbvios, mas eles merecem maior atenção. Em primeiro lugar, é necessário distinguir entre o que é um "ataque autocrático" às instituições típicas de um Estado constitucional (separação de poderes, por exemplo), e as críticas que podem ser levantadas não apenas à atuação do Tribunal nas últimas duas décadas, mas da amplitude das competências estabelecidas pela Constituição. Ora, defender um STF "esvaziado" em termos de competências políticas não é sinônimo de autocracia: o compromisso com o Estado de Direito é perfeitamente compatível com a defesa de um modelo de controle de constitucionalidade a ser exercido com exclusividade por um tribunal constitucional dotado de competências bem mais restritas do que as atualmente possuídas pelo STF. Esse é o modelo adotado na maioria das democracias constitucionais mundo afora, sobretudo na Europa continental. Isso para não mencionar a sabida existência de democracias constitucionais consolidadas que não possuem qualquer forma de controle judicial de constitucionalidade.

Em segundo lugar, é possível questionar se o Tribunal foi mesmo "alçado a guardião da Constituição pela política" e tornado o responsável pela defesa do "pacto social pós ditadura". Não é correto simplesmente supor que "a política", aqui entendida como as forças políticas organizadas, os partidos e agentes relevantes etc., de fato atribuiu ao STF essa competência. É possível que essa "atribuição" seja uma justificativa a posteriori, uma racionalização posterior aos fatos que, no contexto da progressiva judicialização da política intensificada a partir dos anos 2000, passou a ser utilizada como "prova" de uma decisão da Assembleia Nacional Constituinte capaz de legitimar esse mesma expansão de competências judiciais.

Em terceiro lugar, uma tarefa de tal natureza, como na Alemanha dos 1930 e em qualquer outro momento da história, pode demandar força e capacidade de ação institucional que excedem em muito as típicas competências decisórias de tribunais no âmbito de processos judiciais.

Em quarto lugar, por fim, é necessário considerar a hipótese de que o próprio tribunal, no exercício de suas competências, possa oferecer riscos autocráticos à vigência da Constituição. Afinal, boa parte dos argumentos em defesa da jurisdição constitucional que gozam de elevada reputação institucional entre nós (inclusive entre ministros do próprio STF), aponta para um tribunal que pretende atuar não como "guardião", mas sim como "senhor e soberano" da constituição.

Na verdade, o principal mérito do excelente trabalho de Recondo e Weber (2019) é descrever o processo mediante o qual, nos anos recentes, o STF foi levado para o centro da arena política, passando a ser percebido pelos atores políticos como um "igual" - com a óbvia consequência do surgimento de reações políticas. Comentando o chamado "inquérito das fake News", eles afirmam tratar-se de:

uma tentativa de recompor a redoma que tradicionalmente protegia o STF e que foi fragilizada pelas novas gerações de ministros - fosse com brigas internas e estratégias artificiais para favorecer suas agendas próprias fosse contorcendo argumentos, virando casaca e desprezando a jurisprudência do tribunal, fosse usando a imprensa para atacar os adversários. Mas acabou por fragilizar ainda mais a instituição. (RECONDO e WEBER, 2019, p. 25)

Nas últimas décadas no Brasil, o processo crescente de judicialização das mais variadas matérias políticas foi justificado, em grande medida, como uma espécie de respeito ou "efetivação" da supremacia da Constituição. Afinal, "a consequência prática da supremacia da constituição é que matérias que são 
constitucionalizadas ficam além do âmbito do processo legislativo ordinário, portanto da política ordinária" (SAJÒ; UITZ, 2017, p. 24). Esse processo é descrito em termos generosos como uma maior efetivação da Constituição, uma "constitucionalização" do Direito em geral:

um efeito expansivo das normas constitucionais, que se irradiam por todo o sistema jurídico. Os valores, os fins
públicos e os comportamentos contemplados nos princípios e regras da Lei Maior passam a condicionar a validade
e o sentido de todas as normas do direito infraconstitucional. (BARROSO, 2018, p. 535).

Especialmente os próprios ministros do STF passaram a reivindicar para a corte que integram uma espécie e legitimidade política ampliada, cada vez mais em evidente concorrência de funções com o parlamento. Tome-se como exemplo a ADI no 3510 (julgado em 2008), o primeiro caso no qual nossa corte constitucional utilizou o procedimento das audiências públicas. A nova prática de "deliberação" judicial foi celebrada em termos que festejavam a legitimidade política do tribunal. $\mathrm{O}$ então presidente da Corte, Ayres Britto, identificou nas audiências públicas um "notável mecanismo constitucional de democracia direta ou participativa" (STF, 2010, p. 145). Por sua vez, o ministro Gilmar Mendes afirmou:

O Supremo Tribunal Federal demonstra, com este julgamento, que pode, sim, ser uma Casa do Povo, tal qual
o parlamento. Um lugar onde os diversos anseios sociais e o pluralismo político, ético e religioso encontram
guarida nos debates procedimental e argumentativamente organizados em normas previamente estabelecidas.
As audiências públicas, nas quais são ouvidos os expertos sobre a matéria em debate, a intervenção dos amici
curiae, com suas contribuições jurídica e socialmente relevantes, assim como a intervenção do Ministério Público,
como representante de toda a sociedade perante o Tribunal, e das advocacias pública e privada, na defesa de seus
interesses, fazem desta Corte também um espaço democrático. Um espaço aberto à reflexão e à argumentação
jurídica e moral, com ampla repercussão na coletividade e nas instituições democráticas. (STF, 2008, p. 599)

Essas afirmações exemplificam com perfeição uma técnica de discurso muito comum entre os defensores das capacidades judiciais: "construímos [...] um retrato idealizado do julgar e o emolduramos junto com o retrato de má fama do legislar." (WALDRON, 2003, p. 2). Ora, como é possível qualificar de "democracia participativa" um procedimento que permite a alguns pareceristas, durante poucos minutos cada um, oferecerem argumentos a partir dos quais o tribunal decidirá com total autonomia? E é plausível esperar que um Tribunal composto por apenas 11 pessoas seja capaz de representar o povo, ainda que "argumentativamente"? Não seria tal afirmação, oriunda de um de seus membros, apenas a celebração de uma competência política auto-atribuída, sem o necessário respaldo dos representados? Os "discursivamente representados" foram consultados quanto à mudança nas regras do processo representativo? Ou foram apenas "discursivamente informados", de que a partir de agora, estariam representados pelo STF? ${ }^{25}$

Recentemente, outro ministro do tribunal desenvolveu argumentos que radicalizam esse viés, com ainda menos modéstia. Para Luís Roberto Barroso (2017), o STF desempenha diversas funções, sendo a mais conhecida dentre elas a de fiscal "contramajoritário" do processo legislativo. Esse papel é definido nos termos tradicionais, como uma proteção dos direitos fundamentais e das regras do jogo democrático, contra maiorias potencialmente tirânicas. Mas são as duas outras funções definidas por Barroso, a "representativa" e a "iluminista", que chamam mais a atenção. A capacidade representativa se apoia numa imagem essencialmente negativa da política ordinária, que é desqualificada como populista "de esquerda" (na América Latina) e "xenófoba" (na Europa), com debates públicos deteriorados e desconectados da sociedade civil, que vê as instituições representativas com "desconfiança e desprezo" (Cf. BARROSO, 2017, p. 52). Além disso, políticos precisam de recursos vultuosos para disputarem eleições, o que obriga os candidatos a buscarem financiamento econômico e empresariai: "esse fato produz uma inevitável aliança com alguns interesses particulares" (BARROSO, 2017, p. 56), algo que, no entendimento de Barroso, macula o processo legislativo. Por outro lado, a magistratura é enaltecida pela forma de seleção de seus membros, pelo concurso público capaz de selecionar "pessoas vindas de diferentes origens sociais",

${ }^{25}$ Discuti esse caso em Oliveira (2009). 
produzindo assim um "drástico efeito democratizador do judiciário" (BARROSO, 2017, P. 56). E por não dependerem dos vultuosos recursos necessários às campanhas eleitorais, conclui que juízes "são capazes de representar melhor - ou com mais independência - a vontade da sociedade" (BARROSO, 2017 , p. 56). Como então justificar a autoridade do STF, um tribunal cujo aceso sabidamente não apenas não ocorre mediante concurso público, mas demanda indicações presidenciais, aprovação pelo senado e obvias articulações políticas? A resposta de Barroso é surpreendente: "na prática [...] a quase totalidade dos ministros integrantes da Corte é composta por egressos de carreiras jurídicas cujo ingresso se faz por disputados concursos públicos" (BARROSO, 2017, p. 56). Uma aprovação em concurso público para alguma carreira jurídica, normalmente ocorrida no início da vida profissional, é a prova da capacidade representativa do membro da corte constitucional.

Ainda mais controvertida, porém, é a função "iluminista" da corte: "Para além do papel puramente representativo, tribunais constitucionais desempenham, ocasionalmente, o papel iluminista de empurrar a história quando ela emperra." (BARROSO, 2017, p. 60). Barroso reconhece a necessidade de moderação no uso dessa competência, dados os riscos democráticos que ela representa, mas é categórico quanto à autoridade da própria corte para decidir quando exercer tal competência. ${ }^{26}$ Ora, é difícil imaginar uma divergência que exemplifique melhor a natureza do conflito político do que as disputas sobre qual é a "direção correta" para a qual a História deve ser "empurrada". Conferir a uma pequena elite de membros do tribunal a competência para "empurrar" adiante um povo incapaz de "encontrar a direção correta" é algo que evoca menos uma imagem iluminista que a de um déspota esclarecido.

Essas idealizações do Tribunal constitucional, "representante discursivo" ou "iluminista", podem ser criticadas mediante argumentos de "perversidade", com as palavras de Schmitt em Der Hüter der Verfassung: a expansão da justiça para domínios essencialmente políticos não altera a natureza do conflito político. Pelo contrário, além de manter o risco de arbitrariedade existente em toda decisão política, acrescenta o problema da politização da justiça, com seus próprios riscos implícitos. Ao contrário do que ocorre com parlamentos e o poder executivo, o tribunal constitucional não é responsável perante eleitores e estará ainda mais livre para impor sua própria pauta política, discricionariamente. Ora, nem mesmo o mais ardoroso defensor de uma atuação "criativa" dos tribunais pode negar que, ao menos em parte, uma das consequências práticas desse processo tem sido o "emponderamento" das cortes, que agora dispóem de meios para agir politicamente em defesa de seus interesses burocráticos-institucionais particulares. ${ }^{27}$ Naturalmente que essa possibilidade não é suficiente para rechaçar o controle de constitucionalidade, mas sim, deveria bastar para motivar análises mais realistas e menos auto-celebratórias. Afinal de contas, "é mesmo uma das manifestações típicas da vida constitucional que um organismo que toma consciência de sua influência política expanda cada vez mais o alcance de seus poderes" (SCHMITT, 2016, p. 49).

Dadas as definições de "guardião" e "senhor soberano" da Constituição, não é possível identificar na figura de um presidente da República em regime tipicamente presidencialista o guardião da Constituição.

\footnotetext{
${ }^{26}$ Para um debate crítico sobre a tese de Barroso, conferir os trabalhos reunidos em Vieira e Glezer (2017). Para uma crítica ao "neoconstitucionalismo" a partir do "constitucionalismo de otimização", cf. Cláudio Ladeira de Oliveira e Lorenzo Furlan (2019).

${ }^{27}$ Para um exemplo recente: "Em meio à pandemia, STF pressiona contra redução salarial e corte de penduricalho. Em meio à crise econômica desencadeada pelo novo coronavírus, o STF (Supremo Tribunal Federal) tem pressionado o Congresso para preservar o próprio salário e evitar a aprovação da redução de vencimentos e de jornada de trabalho de servidores públicos. [...] Além do lobby em favor da própria remuneração, o Supremo também dá demonstrações de que não quer mexer nos chamados penduricalhos da magistratura, os benefícios que engordam os salários dos juízes. [...] Há anos o excesso de penduricalhos e os supersalários são criticados, inclusive, por ministros do Supremo. A corte, no entanto, hesita em julgar casos que mexam nos vencimentos dos juízes. A decisão liminar (provisória) do ministro Luiz Fux que estendeu o auxílio-moradia a todos os magistrados do Brasil, por exemplo, durou quatro anos e sequer foi julgada pelo plenário. O próprio ministro revogou o benefício, mas sem deixar que a medida afetasse o bolso da categoria: a revogação só ocorreu após o então presidente Michel Temer garantir o reajuste de 16,32\% no teto salarial, que é usado como base para calcular a remuneração dos juízes." (EM MEIO..., 2020)
} 
Ao contrário do que ocorria em Weimar, o presidente da República na CF/88 é também o chefe do poder executivo, não podendo ser visto como um "poder neutro" ("ao lado") em relação aos conflitos entre executivo, legislativo e poder judiciário. Por outro lado, isso não é o suficiente para conferir o status de guardião aos tribunais ou negar ao Presidente da República alguma função - ainda que não exclusiva - de defensor da Constituição. E isso pode ser ilustrado com um exemplo fictício, mas inspirado em eventos dos últimos dias. Imaginem que estamos no ano de 2027, o primeiro do mandato de um presidente da república recém eleito e que nos 8 anos anteriores esteve na oposição ao presidente anterior. Ao final do primeiro ano de governo, em meio a uma considerável crise econômica gestada nos anos anteriores, há um relativo equilíbrio de força entre o novo presidente e a oposição, tanto no Congresso nacional quanto na opinião pública. Imagine que o STF do ano de 2027 possui ampla maioria formada nos anos anteriores. Sua composição é majoritariamente antipática ao novo presidente. Imagine agora que esse STF, diante de alguma situação de grave conflito político, reivindique a autoridade de um "guardião da Constituição" e interprete o artigo $142 \mathrm{da} \mathrm{CF} / 88^{28}$ declarando "omissão inconstitucional" do Congresso Nacional por ausência de lei regulamentadora da função "moderadora das Forças Armadas". A seguir, o tribunal determina que as Forças Armadas atuem para destituir o presidente recém-eleito. Se em tal situação o presidente recém-eleito, com fundamento no juramento presidencial de defender a constituição ${ }^{29}$, se recusar a acatar ordem do tribunal e, com apoio de parcela suficiente das Forças Armadas, conclamar a população às ruas para defender seu mandato e a Constituição, será possível negar ao Presidente, ao menos nesse instante dramático, o status de "guardião da Constituição"?

O fato é que a "judicialização da política" leva inevitavelmente à "politização da justiça": a tentativa de anular o risco de arbitrariedade política transferindo a autoridade das decisões para instituições judiciais produzirá inevitavelmente como resultado a politização dessas instituições. Em primeiro lugar porque seus membros precisarão inevitavelmente decidir qual das alternativas de regulação em disputa valerá de forma impositiva para todos os membros da comunidade, o que em si mesmo será um ato político em sua essência. Em segundo, se tal instituição passa a ser percebida pelos demais agentes políticos como um "participante do jogo", as forças relevantes tentarão ocupar também esse espaço de elevada legislação. Ao fim, o jogo político estará sendo travado de forma menos pública, até certo ponto blindado de críticas em função de certa imagem de imparcialidade judicial ainda remanescente, mas de forma não menos intensa ou potencialmente arbitrária.

\section{Conclusão.}

As lições de Schmitt são mais negativas que propositivas, mas são uteis ainda assim. Certamente não devem levar à conclusão de que, no sistema da $\mathrm{CF} / 88$, o presidente da república é "o" guardião da Constituição. Afinal, em nosso sistema, o presidente não é um "terceiro neutro", mas chefe do poder executivo. Além disso, a competência para a "guarda e defesa" da Constituição não é sinônimo de "controle judicial de constitucionalidade". Tribunais não podem ser considerados "guardiões da Constituição" por uma simples questão de fato: a ausência de força política e institucional que os habilite a tanto. E se a defesa da Constituição demanda alguma competência política, o melhor a fazer é investir na construção de arranjos institucionais que distribuam competências entre as instancias explicitamente políticas de forma adequada: o secular "remédio" dos "freios e contrapesos". Que inclusive é compatível com a adoção de modelos de controle de constitucionalidade com a competência concentrada "tribunais" especialmente criados para

\footnotetext{
${ }^{28} \mathrm{CF} / 88$, Art. 142. As Forças Armadas, constituídas pela Marinha, pelo Exército e pela Aeronáutica, são instituições nacionais permanentes e regulares, organizadas com base na hierarquia e na disciplina, sob a autoridade suprema do Presidente da República, e destinam-se à defesa da Pátria, à garantia dos poderes constitucionais e, por iniciativa de qualquer destes, da lei e da ordem.

${ }^{29}$ Art. 78. O Presidente e o Vice-Presidente da República tomarão posse em sessão do Congresso Nacional, prestando o compromisso de manter, defender e cumprir a Constituição, observar as leis, promover o bem geral do povo brasileiro, sustentar a união, a integridade e a independência do Brasil.
} 
tal fim, dada sua evidente natureza política, mais que "jurisdicional". Sobretudo se tal corte exercer suas competências respeitando padrões de auto-restrição no trato de matérias politicamente controvertidas. Além disso, a ampliação da atuação judicial é ela própria fonte de potenciais arbítrios. A pretensão de subordinar todas as questões políticas fundamentais à a autoridade de tribunais é capaz de ampliar a mesma arbitrariedade política que se desejava combater, apenas alterando seu "habitat institucional": não mais instituições eleitorais e representativas, mas um tribunal que se pretende soberano, não guardião.

A Constituição de 1988 foi gestada em meio a um ambiente político no qual prevalecia o receio de um executivo autoritário, jamais ameaçado por um legislativo totalmente subjugado. Contra isso "precauções" judiciais deveriam ser levantadas. Isso explica a adoção de um sistema de controle de constitucionalidade que autoriza uma ampla revisão judicial das decisões políticas legislativas, inclusive das "omissões" legislativas. Nos anos seguintes a 1988, dada a situação típica de sistema institucional estável (forças políticas relevantes se comportavam com razoável fidelidade ao texto da constituição), conferiu plausibilidade às descrições mais idealizadas da "supremacia da constituição" como se efetivamente vigorasse uma supremacia de fato da Constituição sobre a política. E a disseminada percepção de rejeição da política partidária e legislativa reforçou a opinião de que as "precauções" constitucionais contra o "risco de arbítrio político" eram ainda mais necessárias. Assim, a cada percepção de um novo "risco", maior a demanda por "judicialização" dos conflitos políticos, mais autonomia das instituições judiciais. No entanto, ainda que o culto doutrinário à judicialização dificulte a reflexão mais aprofundada sobre tais temas, os defensores de uma jurisdição constitucional expansiva e criativa precisam optar: ou o STF tem legitimidade para legislar, ainda que sob formas processuais filosoficamente ornamentadas, e então é razoável esperar que todas as forças políticas com alguma capacidade de influência estejam representadas no tribunal; ou então o STF deve adotar posturas de auto-restrição e reduzir dramaticamente a judicialização da política que marcou as últimas décadas. Defender um STF legislador e, simultaneamente, rejeitar que forças políticas com capacidade de pressão ocupem espaço no tribunal, mais que uma contradição teórica, é enorme ingenuidade prática.

\section{Referências bibliográficas.}

ALEXY, Robert. Constitucionalismo Discursivo. 4a ed. Porto Alegre: Livraria do Advogado, 2015.

BARROSO, 2017. A Razão sem voto: o Supremo Tribunal Federal e o governo da maioria. In VIEIRA, Oscar Vilhena; GLEZER, Rubens (orgs). A Razão e o Voto: diálogos institucionais com Luís Roberto Barroso. São Paulo: FGV, 2017, pp. 25-75.

BARROSO, Luís Roberto. Curso de Direito Constitucional Contemporâneo: os conceitos fundamentais e a construção do novo modelo. $7^{\mathrm{a}}$ ed. São Paulo: Saraiva, 2018.

BÖCKENFÖRDE, Ernst-Wolfgang. Constitutional and Political Theory: selected wrintings. Vol. 1. KÜNKLER, Mirjam. STEIN, Tine (orgs). New York: Oxford University Press, 2017.

BRASIL. Código Civil: Lei 10406 de 10 de janeiro de 2002. Disponível em http://www.planalto.gov.br/ ccivil_03/leis/2002/110406.htm. Acesso em 15/02/2020. 
BRASIL. Supremo Tribunal Federal STF. Ação Direta de Inconstitucionalidade n. 3510 -DF. Requerente: Procurador-Geral da República. Requerido: Presidente da República. Julgamento: 29/05/2008. Publicação: 28/05/2010. Disponível em http://redir.stf.jus.br/paginadorpub/paginador.jsp?docTP=AC\&docID=611723, acesso em 15/03/2020.

CALDWELL, Peter C. Popular Sovereignty and the Crisis of German Constitutional Law: the theory and practice of Weimar Constitutionalism. Durham: Duke University Press, 1997.

DAHL, Robert. Decison-making in a democracy: the suprem court as a national police-maker". Journal of Public Law, n. 6, 1957, pp. 279-295.

DUTRA, Delamar Volpato. A Constituição brasileira e a crise da democracia. Eleuthería, v. 3, p. 13-20, 2018.

ELSTER, Jon. Ulisses Liberto: estudos sobre racionalidade, pré-compromisso e restrições. São Paulo: Unesp, 2000.

EM MEIO à pandemia, STF pressiona contra redução salarial e corte de penduricalho. Valor Econômico. São Paulo, 11 de julho de 2020, disponível em https://valor.globo.com/politica/noticia/2020/07/11/ em-meio-pandemia-stf-pressiona-contra-reduo-salarial-e-corte-de-penduricalhos.ghtml. Acesso em 15 de julho de 2020.

HAMILTON, Alexander. MADISON, James. JAY, John. O Federalista. 2ª ed. Lisboa: Fundação Calouste Gulbenkian, 2011.

HIRSCHL, Ran. Towards Juristocracy: the origins and consequences of the new constitutionalism. Cambridge: Harvard University Press, 2004.

KALYVAS, Andreas. Democracy and the Politics of the Extraordinary Max Weber, Carl Schmitt, and Hannah Arendt. Cambridge University Press: New York, 2008.

KELSEN, Hans. Jurisdição Constitucional. São Paulo: Martins Fontes, 2003

KRIELE, Martin. Introdução à Teoria do Estado: os fundamentos históricos da legitimidade do Estado Constitucional Democrático. Porto Alegre: Sérgio Antonio Fabris Editor, 2009.

LAMEGO, José. A Teoria Pura do Direito de Kelsen. Lisboa: Almedina, 2019.

MACEDO Jr., Ronaldo Porto. Carl Schmitt e a Fundamentação do Direito. 2a ed. São Paulo: Saraiva, 2011.

MEHRING, Reinhard. Carl Schmitt: a biography. Cambridge: Polity Press, 2014.

MEIERHENRICH, Jens. SIMONS, Oliver (orgs). The Oxford Handbook of Carl Schmitt. New York: Oxford University Press, 2016

OLIVEIRA, Cláudio Ladeira de. "Direito como Integridade" e "Ativismo Judicial": algumas considerações sobre uma decisão do Supremo Tribunal Federal. In MARTEL, Leticia de Campos Velho (org). Estudos Contemporâneos de Direitos Fundamentais. Vol. II. Rio de Janeiro: Lumen Juris, 2009, pp. 237-265.

OLIVEIRA, Cláudio Ladeira de. FURLAN, Lorenzo Emanuelli. Do Neoconstitucionalismo ao Constitucionalismo da Otimização: um estudo crítico do Resp 19392 PI - o caso da fraude à "cota de gênero". In OLIVEIRA, Cláudio Ladeira de. DUTRA, Delamar Volpato. MARTINS, Argemiro Cardoso Moreira (orgs). Ensaios sobre Constitucionalismo Político. Vol. 1. Florianópolis: Habitus, 2019. 
PAULSON, Stanley. Hans Kelsen and Carl Schmitt: Growing Discord, Culminanting in the "Guardian" Controversy of 1931, in MEIERHENRICH, Jens. SIMONS, Oliver (orgs). The Oxford Handbook of Carl Schmitt. New York: Oxford University Press, 2016, pp. 510-546.

POSNER, Eric. VERMEULE, Adrian. Demystifying Schmitt, in MEIERHENRICH, Jens. SIMONS, Oliver (orgs). The Oxford Handbook of Carl Schmitt. New York: Oxford University Press, 2016, pp. 612-626.

POSNER, Eric. VERMEULE, Adrian. The Executive Unbond: after the madionian Republic. New York: Oxford University Press, 2010.

PREU $\beta$, Ulrich. Carl Schmitt and the Weimar Constitution, in MEIERHENRICH, Jens. SIMONS, Oliver (orgs). The Oxford Handbook of Carl Schmitt. New York: Oxford University Press, 2016, pp. 471-489.

PRZEWORSKI, 1994. Democracia e Mercado. São Paulo: Cia das Letras, 1991

RECONDO, Felipe. WEBER, Luiz. Os Onze: o STF, seus bastidores e suas crises. São Paulo: Cia das Letras, 2019.

SAJÒ, András. UITZ, Renáta. The Constitution of Freedom: an Introduction to legal constitutionalism. New York: Oxford University Press, 2017.

SCHMIT, Carl. Der Hüter der Verfassung. 5a ed. Berlin: Duncker \& Humblot, 2016;

SCHMITT, Carl. Der Wert des Staates und die Bedeutung des Einzelnen. Tübingen: Verlag von J. C. B. Mohr, 1914.

SCHMITT, Carl. Legality and Legitimacy. Durham: Duke University Press, 2004.

SCHMITT, Carl. Posiciones ante el Derecho. Madrid: Tecnos, 2012

SCHMITT, Carl. Verfassungslehre. 9a ed. Berlin: Duncker \& Humblot, 2003.

SCHMITT, Carl. Verfassungsrechtliche Aufsätze aus den Jahren 1924 - 1954: Materialien zu einer Verfassungslehre. $3^{\mathrm{a}}$ ed. Berlin: Dunker \& Humblot, 1985.

SCHUPMANN, Benjamin A. Carl Schmitt's State and Constitutional Theory: a critical analysis. Londres: Oxford University Press, 2017

SOARES, Guilherme. Controvérsias interpretativas entre Advocacia de Estado e Tribunais de Contas. Direito do Estado em Debate - Revista Jurídica da Procuradoria Geral do Estado, v. 8, p. 9-31, 2017.

STRAUS, Leo. Direito Natural e História. São Paulo: WMFMartinsfontes, [1950] 2014

THAYER, James Bradley. The Origin and Scope of the American Doctrine of Constitutional Law. Harvard Law Review, vol. 7, n. 3, 1893, pp. 129-156.

VERMEULE, Adrian. The Constitution of Risk. New York: Cambridge University Press, 2014.

VIEIRA, Oscar Vilhena; GLEZER, Rubens (orgs). A Razão e o Voto: diálogos institucionais com Luís Roberto Barroso. São Paulo: FGV, 2017

WALDRON, Jeremy. A Dignidade da Legislação. São Paulo: Martins Fontes, 2003. 